\title{
INSECT SUCCESSION PATTERN ON DECOMPOSING PIG CARCASSES IN TASMANIA: A SUMMER STUDY
}

\author{
by Paola A. Magni, J. David North, Melle Zwerver, lan R. Dadour
}

(with one text- igure, two plates and one table)

\begin{abstract}
Magni, P.A., North, J.D., Zwerver, M., Dadour, I.R. 2019 (14:xii). Insect succession pattern on decomposing pig carcasses in Tasmania: a summer study. Papers and Proceedings of the Royal Society of Tasmania 153: 31-38. https://doi.org/10.26749/rstpp.153.31 ISSN 0080-4703. Discipline of Medical, Molecular \& Forensic Sciences, Murdoch University, 90 South St, Murdoch, Western Australia 6150, Australia (PAM, IRD). Murdoch University Singapore, King's Centre, 390 Havelock Road, Singapore 169662 (current address: PAM). Tasmania Police Forensic Services, 37-43 Liverpool Street, Hobart, Tasmania 7000, Australia (JDN). Tasmania Police, Devonport Police Station, 24 Wenvoe Street, Devonport, Tasmania 7310, Australia (MZ). *Author for correspondence: Email: P.Magni@murdoch.edu.au.
\end{abstract}

Insect succession has been studied around the world using the predictable and mostly sequential arrival pattern of different insect species that are attracted to a decomposing carcass. In cases of suspicious death of humans and animals, carrion insects may be used to assist in crime scene reconstruction. The present research represents the first study in forensic entomology to be undertaken in Tasmania, investi-gating insect succession patterns on decomposing pig carcasses and providing a preliminary database of forensically important insects. Six pig carcasses were placed in two contrasting locations (rural and urban) in northern Tasmania. Insect successional waves were recorded over a 40-day study during the austral summer season. Results showed that decomposition rates and insect assemblages varied between each location. Eleven insect taxa, representing nine families, were identified in association with the decomposition of the pig carcasses at both localities. Blowflies present on the pig carcasses throughout the decomposition process were Calliphora stygia Malloch (Diptera: Cal-liphoridae) at both sites and Lucilia sericata (Meigen) at the urban site only. These preliminary results will provide useful information in any future casework involving human remains and associated insect material in Tasmania.

Key Words: decomposition, Tasmania, insect succession, forensic entomology, blowflies.

\section{INTRODUCTION}

Forensic entomology is the study of insects and other arthropods associated with legal investigations (Voss et al. 2009). Forensic entomology is a method used worldwide to assist in determining a more accurate time since death or minimum Post Mortem Interval (minPMI) (Goff 1993 , Voss et al. 2009). Other data gleaned from insect succession patterns have become invaluable during legal investigations. They can be used in conjunction with other methods to assist in the overall crime scene reconstruction, movement of the body, the presence of toxicological substances (Wallace 2017, Magni et al. 2018) and foreign DNA in the alimentary tract (Carvahlo et al. 2005, Di Luise et al. 2008). Insects can also indicate the presence of lesions in cases of suspicious death (Byrd \& Castner 2010).

The decomposition of organic matter involves a very complex biological process whereby the body undergoes several different — but generally predictable — stages (typically fresh, bloated, advanced, dry, skeletal) (Goff 1993). The decomposition process is largely dependent on factors such as geographical location and environmental conditions (habitat, biogeography and accessibility by the fauna), deposition conditions (e.g., surface, burial or submersion) and climatic conditions (e.g., temperature, season) (Voss et al. 2011, Hyde et al. 2015, Roberts et al. 2017). Furthermore, extrinsic and intrinsic properties that each human cadaver exhibits - e.g., gut microbiome, size, cause of death, presence/absence of clothes - should also be considered (Gill 2005, Voss et al. 2009, Benbow et al. 2015, Iqbal et al. 2018).
During the process of decomposition, remains can attract a variety of organisms that utilise the cadaver as a food source, a reproduction site, and as a predator and/ or parasite on the fauna present on the remains (Payne 1965, Schotsmans et al. 2017). In general, the majority of the fauna present on the remains is represented by insects, mainly as blowflies, flesh flies and house flies (Family Diptera) and carrion beetles (Family Coleoptera) (Morris $\&$ Dadour 2015). The arrival of insects is not random, but associated with certain stages of decomposition (Mégnin 1894). Insect succession involves the process of invasion by insects onto the carcass soon after death and continues by attracting subsequent insect species in successional waves (Smith 1986, Gill 2005, Voss et al. 2008).

Several studies have shown that approximately 48-72 hours after a death, the use of insects attracted to the body is the most accurate method to estimate the minPMI (Goff 1991, Byrd \& Castner 2010, Marks et al. 2010). To provide reliable information for investigation purposes an entomologist must correctly identify the insects' species and age, and if possible utilise an appropriate database of the insect succession pattern for the specific geographical region where the remains were discovered. In Australia, the majority of insect succession studies that have been published are based in New South Wales and the Australian Capital Territory (Fuller 1934, Johnson et al. 2013, Forbes et al. 2014, Gherlenda et al. 2016, Barton et al. 2017), Victoria (Archer \& Elgar 2003, Archer et al. 2005), Queensland (O'Flynn 1983, Farrell et al. 2015) and Western Australia (Bornemissza 1957, Dadour et al. 2001, 
O’Brien et al. 2007, Voss et al. 2008, 2009, 2011, Magni et al. 2019). To date, there has been one published study detailing insect succession patterns on decomposing remains in Tasmania (Lang et al. 2006). That study concerned the species of blowflies that emerge from a possum carcass and how they might affect blowfly strike of sheep over autumn and winter. No emphasis was placed on how such species might be used in a forensic context. Tasmania has been geographically and genetically isolated for long periods (McCalman 2009), and as a consequence entomological data on necrophagous insects from this region rather than mainland Australia are essential in legal investigations to assist in determining a minPMI.

The aim of the present study is to provide a preliminary database, detailing forensically important insects, mainly blowfly species, attracted to decomposing carcasses at two locations in northern Tasmania during the austral summer. Commonalities and dissimilarities were investigated at two contrasting habitats, rural and urban over a 40-day study period.
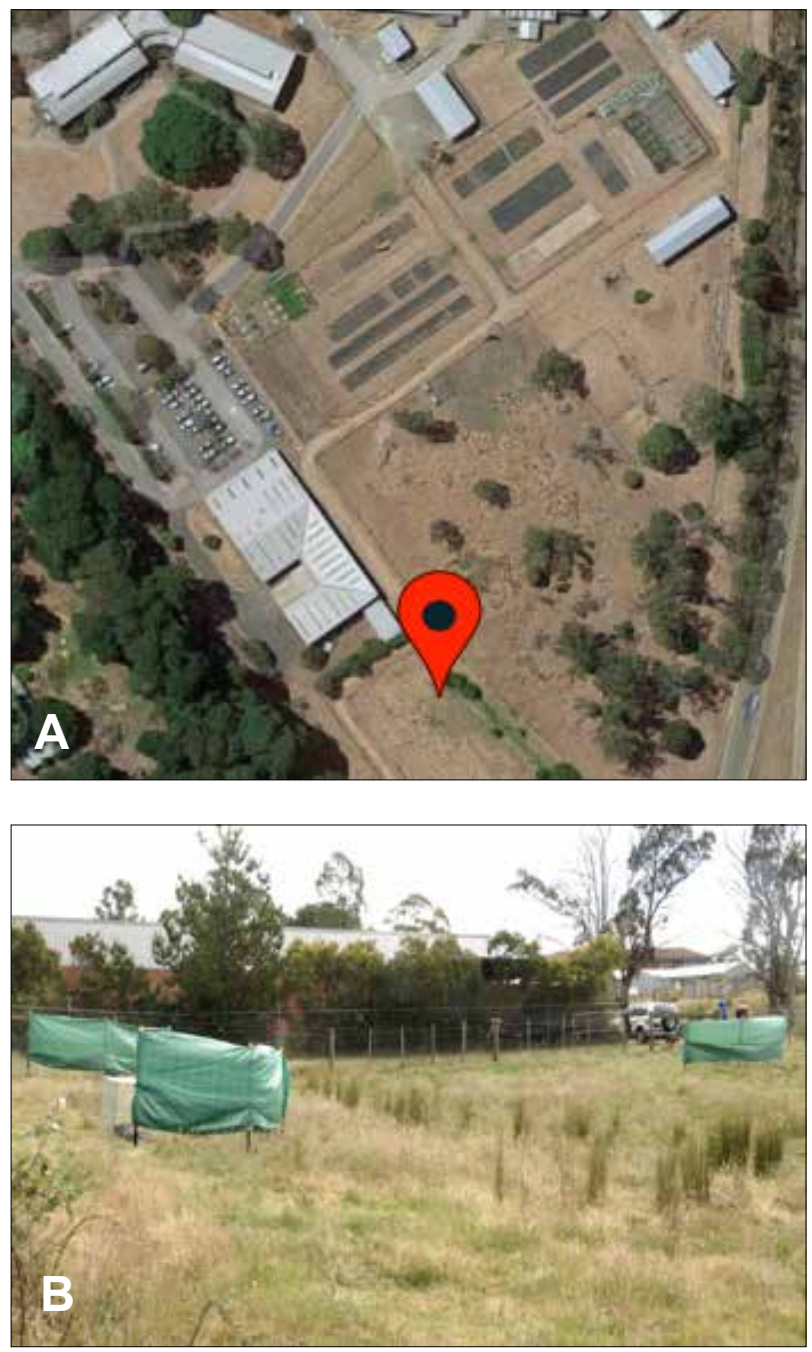

\section{MATERIALS AND METHODS}

\section{Study sites}

A 40-day survey of animal decomposition was conducted at two study sites from 12 December 2014 to 20 January 2015. The first study site (rural site, RS) was located within a paddock situated approximately $8 \mathrm{~km}$ northeast of Devonport, Tasmania (4110'26.6"S, 146²17'23.6"E) (pl. 1C, D). The site was adjacent to an area used primarily for potato cultivation. No pesticides were used during the 40-day trial. The second study site (urban site, US) was located within a scientific facility (Department of Primary Industries, Parks, Water and Environment Facility) situated approximately $5 \mathrm{~km}$ south of Launceston, Tasmania (41 $\left.28^{\prime} 09.8^{\prime \prime} \mathrm{S}, 147^{\circ} 08^{\prime} 28.6^{\prime \prime E}\right)$ (pl. 1A, B). The area used for the study was approximately $0.13 \mathrm{~km}$ south of the main facility: it was surrounded by a grass paddock with buildings, roads and trees nearby. The two study sites were situated approximately $100 \mathrm{~km}$ apart.
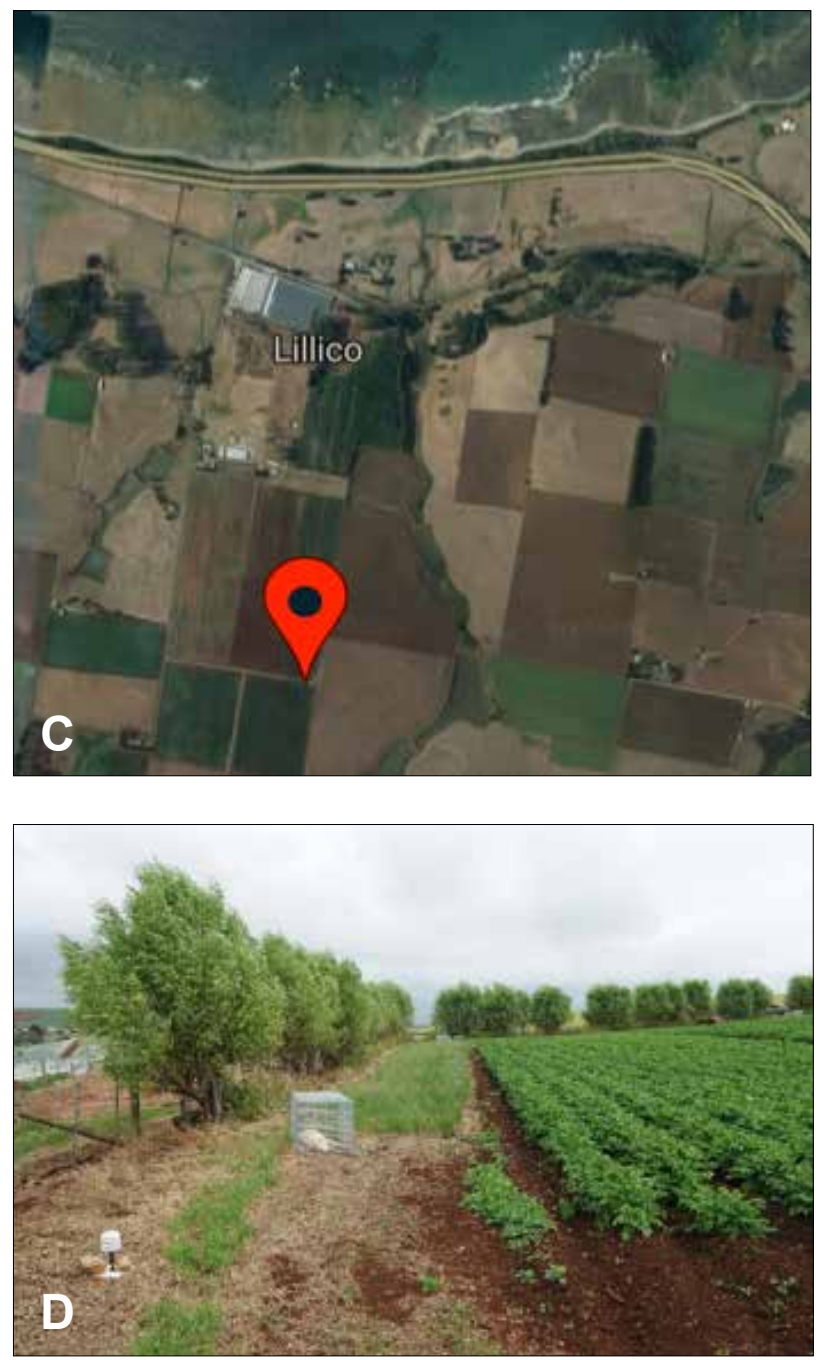

PLATE 1 - Study locations, urban site (A, B) and rural site (C, D). Credit for A and C: Google maps https://www.google.com/maps/. 


\section{Experimental design}

In Australia and in many other countries, the field-based research of surface decomposition of human remains is legally prohibited outside of licensed facilities such as the Australian Facility for Taphonomic Experimental Research (Smith 1986, Knobel et al. 2018, Luong et al. 2018). As a result, animal models, such as dogs, rats, pigs and guinea pigs as well as bait and sticky-based fly traps are the only option available for research relating to insect succession data and to provide information based on geographic location and seasonality pertaining to minPMI (Dadour et al. 2001). Pigs (Sus scrofa domesticus Erxleben) are the preferred animal model and most commonly used (Schoenly \& Hall 2002), as they represent the most reliable facsimile to humans. Furthermore, pigs are reasonably inexpensive and can be readily available in numbers with uniform mass and size similar to humans (Dadour et al. 2001, Gill 2005). In the present study, a total of six pigs weighing $45 \pm 5 \mathrm{~kg}$ were used. The pigs were obtained from a commercial piggery and within two hours of being head bolted, the pig carcasses were transported and placed in each of the study sites. This represented Day 1 of the experiment. In both the RS and US, three pigs were placed $10 \mathrm{~m}$ apart from each other and protected by individual scavenger-proof cages constructed by the authors (Dadour et al. 2001). The design of the mesh (metal) cage prevented animal scavenging but still allowed insect access.

Sampling of the insect fauna was conducted over a 40-day period. Representative samples of insect fauna were collected in accordance with forensic entomology guidelines. Insects colonising the carcasses were sampled daily for the first week and subsequently every two to four days for the 40-day period. Following collection, samples were labelled in relation to collection site, sampling date and time, carcass number and anatomical site of collection. As per the best practice in forensic entomology (Amendt $e t$ al. 2007), half the insect samples were sacrificed to allow the identification of the age at the time of collection, while the other half were allowed to reach the adult instar stage to facilitate identification (Byrd \& Tomberlin 2010). For this purpose, fauna boxes $25 \times 14 \times 13 \mathrm{~cm}$ with a base of white sand and beef liver placed on top were used to rear the immatures (Byrd \& Tomberlin 2010).

The preserved samples and trapped adult fly samples were observed under a steromicroscope (Leica ${ }^{\circledast}$ MZ8). Larvae were aged in terms of instar and taxonomically identified to family/genus/species) by an insect taxonomist. The preserved samples were separated and organised according to collection site, carcass number and date of collection. Due to its forensic perspective, this study was mostly focused on blowflies.

\section{Environmental data}

Daily records of ambient temperature were obtained from weather stations at the sites of decomposition and surrounds from local weather stations in both localities (fig. 1). The weather stations were within $5 \mathrm{~km}$ from the RS and US sites respectively. Records of rainfall levels were obtained from the Bureau of Meteorology website (Bureau of Meteorology 2017) (fig. 1).

\section{Assessment of the stage of decomposition}

In addition to insect sampling, all carcass replicates were observed and assessed daily for the first week and subsequently every two to four days for the 40-day period. Photographs of the carcasses were taken each observation day (pl. 2). The decomposition process was determined using the five stages described by Goff (1993). Carcasses were considered in the fresh stage from the moment of death to the onset of bloat. Bloat commenced when inflation of the carcass occurred and concluded upon deflation of the carcass. The decay stage was considered from carcass deflation and the outer layer of the skin on the carcass becomes broken leaving only dry constituents remaining which is the commencement of the dry stage. Carcasses were considered as skeletonised when the absence of soft tissue was noted on bones, and only cartilage and hair remained.
FIG. 1 - Comparative view of the environmental data (average ambient temperature and rainfall) of the two location sites, rural and urban, over the duration of the 40-day study.

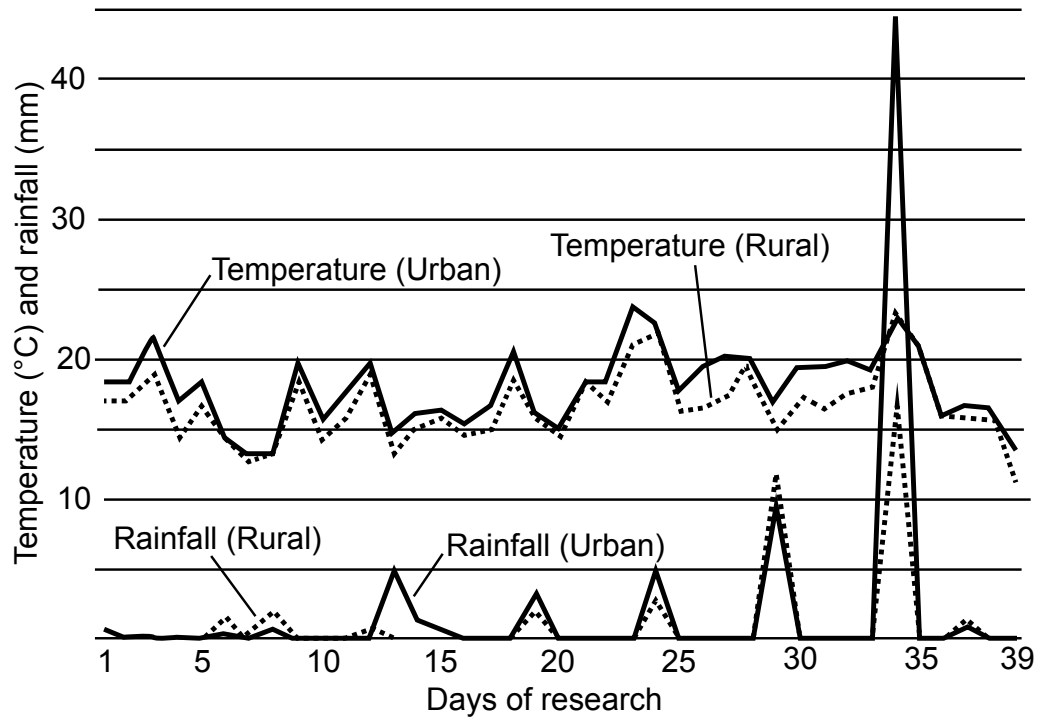


URBAN SITE
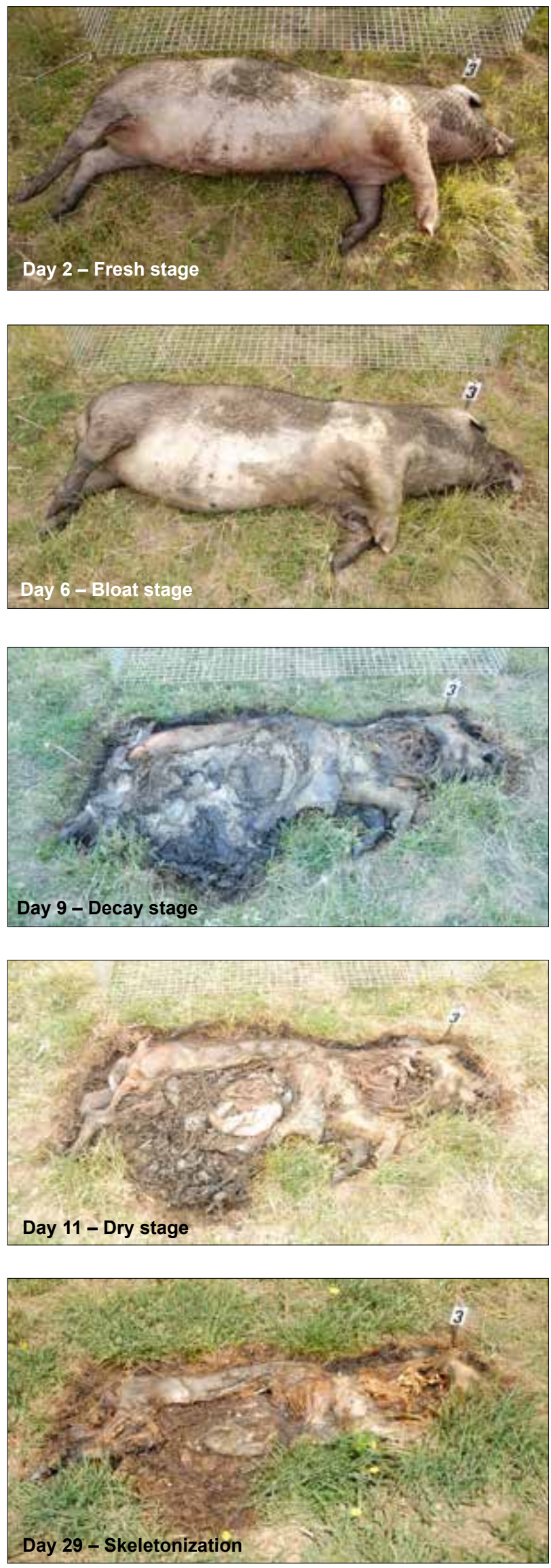

RURAL SITE
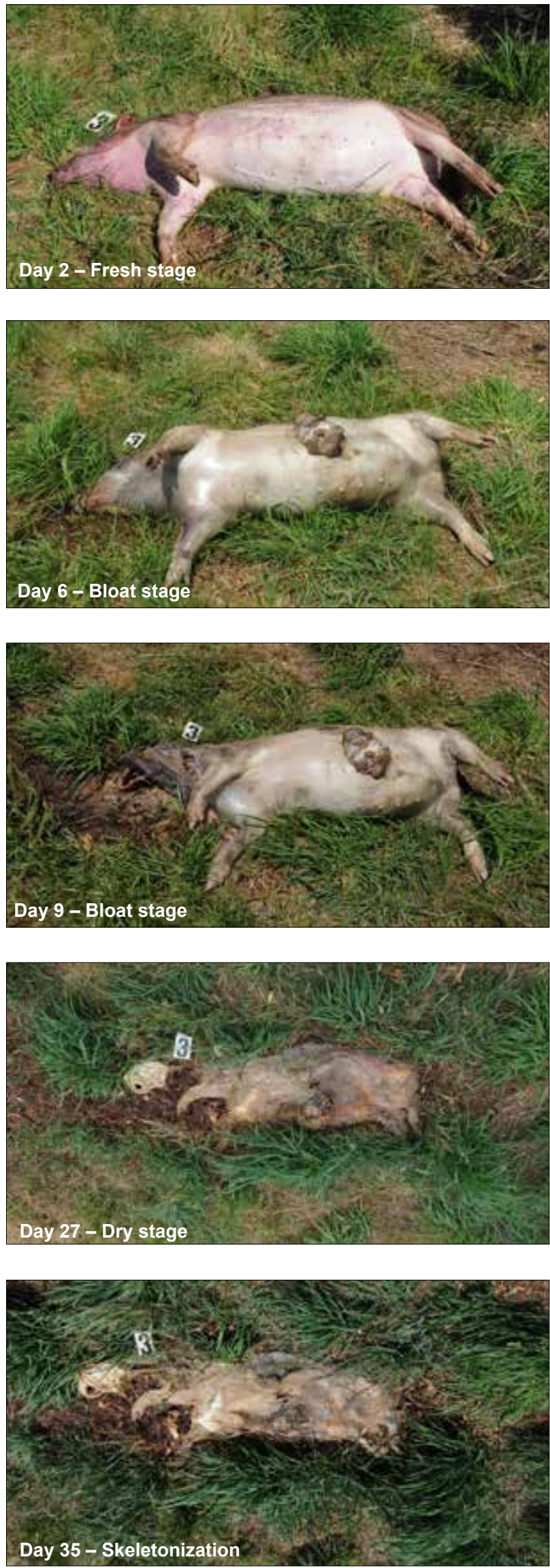

PLATE 2 - Decomposition process at various stages at the two study sites, urban and rural. 
TABLE 1 - Summer succession of insects on carcasses at two study sites, urban site and rural site, over $\mathbf{4 0}$ days in Tasmania, Australia. Data are summarised by decomposition stages. Data for the three carcass repetitions were combined in this table.

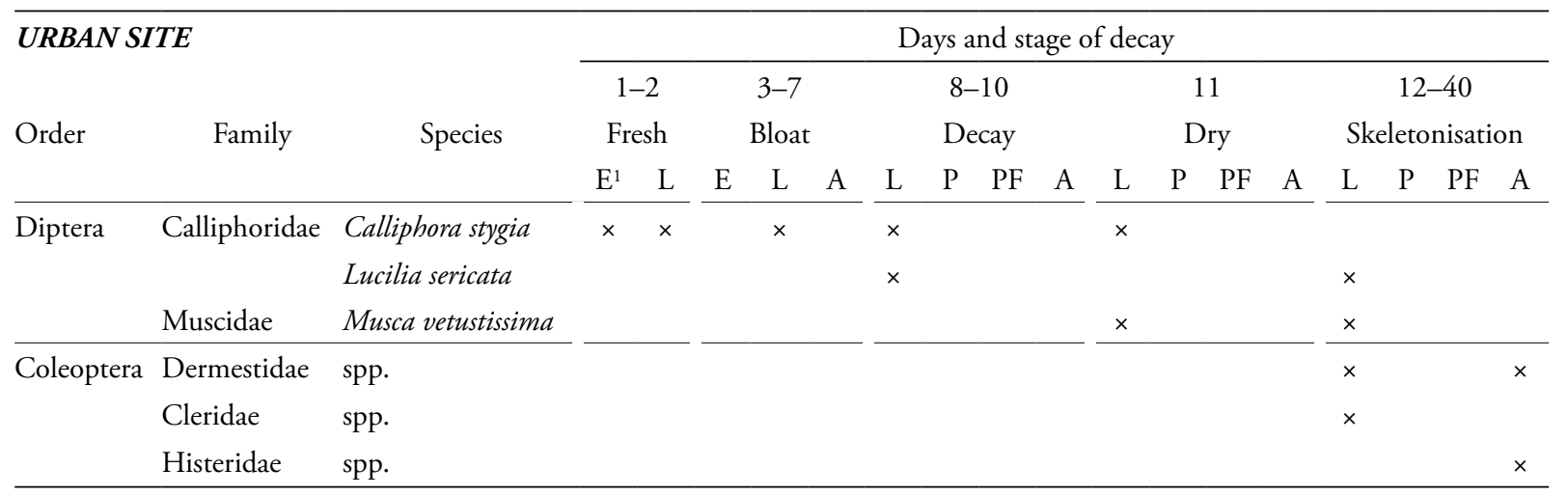

\begin{tabular}{|c|c|c|c|c|c|c|c|c|c|c|c|c|c|c|c|c|c|c|c|}
\hline \multirow{2}{*}{\multicolumn{3}{|c|}{ RURAL SITE }} & \multicolumn{17}{|c|}{ Days and stage of decay } \\
\hline & & & & & & $4-9$ & & & & -24 & & & & -31 & & & & -40 & \\
\hline \multirow[t]{2}{*}{ Order } & \multirow[t]{2}{*}{ Family } & \multirow[t]{2}{*}{ Species } & & & \multicolumn{3}{|c|}{ Bloat } & \multicolumn{4}{|c|}{ Decay } & \multicolumn{4}{|c|}{ Dry } & \multicolumn{4}{|c|}{ Skeletonisation } \\
\hline & & & $\mathrm{E}$ & $\mathrm{L}$ & $\mathrm{E}$ & $\mathrm{L}$ & A & $\mathrm{L}$ & $\mathrm{P}$ & $\mathrm{PF}$ & A & $\mathrm{L}$ & $\mathrm{P}$ & $\mathrm{PF}$ & A & $\mathrm{L}$ & $\mathrm{P}$ & $\mathrm{PF}$ & A \\
\hline \multirow[t]{2}{*}{ Diptera } & Calliphoridae & Calliphora stygia & $x$ & $x$ & $x$ & $x$ & & $x$ & $x$ & $x$ & & & $x$ & & & & $x$ & & \\
\hline & Muscidae & Musca vetustissima & & & & $x$ & & $\times$ & & $x$ & & $x$ & & $x$ & & $x$ & & $x$ & \\
\hline \multirow[t]{7}{*}{ Coleoptera } & Forficulidae & spp. & & & & & & & & & & & & & & & & & $x$ \\
\hline & Staphylinidae & spp. & & & & & $x$ & $x$ & & & & $x$ & & & & $x$ & & & \\
\hline & Dermestidae & spp. & & & & & $x$ & & & & & $x$ & & & $x$ & $x$ & & & $x$ \\
\hline & Cleridae & spp. & & & & & & & & & $x$ & & & & $x$ & & & & $x$ \\
\hline & Silphidae & spp. & & & & $x$ & $x$ & $x$ & & & & & & & $x$ & & & & \\
\hline & Carabidae & spp. & & & & & & & & & $x$ & & & & & & & & \\
\hline & Histeridae & spp. & & & & & $\times$ & & & & $\times$ & & & & & & & & \\
\hline
\end{tabular}

${ }^{1}$ Life stages are identified by E (eggs), L (larvae), P (pupae), PF (larva in post-feeding instar) and A (adults). $\times=$ specimen collection.

\section{RESULTS}

\section{Decomposition process and environmental data}

The progression and duration of each decomposition stage were not entirely comparable between the two sites over the 40 days (table 1). While the first stages of decomposition were approximately the same duration (Fresh stage: US 3 days, RS 3 days; Bloat stage: US 4 days, RS 5 days), the subsequent stages required a different time to be completed (Decay stage: US 2 days, RS 14 days; Dry stage: US 3 days, RS 6 days; Skeletonisation stage: US from day 12 of the experiment, RS from day 32 of the experiment) (table 1 ). Overall, the decomposition in the RS happened at a slower rate compared to that at US. In particular, while both carcasses remained relatively fresh until Day 3, the duration of the decay stages lasted up to 24 days at RS but only 10 days at US, with all carcass replicates reaching the dry/remains stage by Day 25 (table 1, pl. 2). The reason for this may be a consequence of the environmental temperatures at the RS which typically had lower minimum temperatures than the US (fig. 1). The RS showed an average minimum temperature of $11.2^{\circ} \mathrm{C}$ and maximum temperature of $23.6^{\circ} \mathrm{C}$, in comparison to the US site where the ambient temperatures were at an average minimum temperature of $13.2^{\circ} \mathrm{C}$ and maximum temperature of $22.5^{\circ} \mathrm{C}$ (fig. 1 ).

\section{Insect succession}

Throughout this study, 11 insect taxa, representing nine families, were identified in association with the decomposition of the pig carcasses (table 1). In both US and RS, representatives of the order Diptera were the primary colonisers of all the carcasses. Two genera of fly were present on the pig carcasses throughout the decomposition process at both the RS and US. Early colonisers arriving during the fresh stage of decomposition were Calliphora stygia Malloch (Diptera: Calliphoridae). The secondary coloniser, Lucilia sericata (Meigen) (Diptera: Calliphoridae) reached the pig carcasses during the bloat stage, but only in the US. A review of the biology and distribution of Lucilia species is detailed by Zumpt (1965), and the Calliphora by Wallman \& Adams (1997). Additional colonisers arriving later during decomposition (at 10 days) included the flies of the family Muscidae (Musca vetustissima Walker) (Hughes 1970) (pl. 2). 
Eggs and larvae of $C$. stygia were observed on carcasses at US from Day 1 of the experiment, and were present up until the skeletonisation stage. L. sericata, instead, appeared on Day 8, while $M$. vetustissima and various carrion beetles were more prevalent after Day 11 . In contrast, eggs and larvae of $C$. stygia were observed on the pig carcasses present at the RS as well, but only up until the dry/ remains stage. Pupae of $C$. stygia were then present until the skeletonistion stage of decomposition. $M$. vetustissima was present during the early stages of decay and remained present until the skeletonisation stages. Beetles were also present at various stages, but in no predictable order during the decomposition process.

\section{DISCUSSION}

This is the first forensically focused study recording the decomposition process and the succession patterns of necrophagous insects on decomposing pig carcasses at two locations in Tasmania during the austral summer.

Comparable research that may be considered relevent was previously conducted some $450 \mathrm{~km}$ away on mainland Australia in Victoria (Archer \& Elgar 2003). The Victorian study highlighted that insect succession patterns change according to the geographical region, but as the study did not account for temperatures, they were only able to suggest that seasonal differences were probably important. In accordance with this research, the present study shows that both the decomposition process and the insect assemblages collected from the carcasses placed in two different environmental locations, RS and US, differed between and over the study period (table 1). As only one previous study has been published in Tasmania during the autumn/winter period (Lang et al. 2006), a comparative analysis was unable to be conducted to determine whether the insect assemblages observed at the two locations are consistent throughout Tasmania.

The different environmental temperatures recorded at the two sites were found to be the main factors that affected both the duration and the extent of the decomposition of the carcasses. The environmental temperatures at the RS were typically lower in comparison to the US, leading to a slower rate of decomposition at the RS and a difference in insect colonisation (table 1). In both US and RS, insects species belonging to the family Calliphoridae appeared early on in the decomposition process stages and remained for the 40 days of the study. In comparison, the M. vetustissima family appeared at a much later stage (from Day 11) of the decomposition process and remained present for the rest of the study. This pattern of insect succession is consistent with previous studies within Australia, even when the study was carried out for longer periods (Voss et al. 2008, 2009, McIntosh et al. 2017). However, these studies contained a much larger array of insect colonisers as they were recorded over one or two seasons in different habitat types and geographical regions.
The validity of applying collected reference data from one habitat for analysis in another within the same geographic region is considered precarious in forensic cases when estimating the time since death based on insect assemblages (Abd El-bar \& Sawaby 2011, Alves et al. 2014). Variation between habitats is known to alter decomposition rates and thus influence insect succession patterns (Campobasso et al. 2001). As evident in this study, decomposition rates vary according to different habitat types (pl. 2) as well as variations in insect colonisation, but, for the most part, the insect succession patterns were reasonably consistent (table 1). Variations in insect succession patterns are usually related to the species' habitat preferences (Voss et al. 2009). Although present at the US site, L. sericata was not detected at the RS site. One explanation is that Lucilia species have a preference for higher temperatures compared to Calliphora species (Smith 1986). As well, L. sericata tends to prefer urban habitats only in Australia (Monzu 1977). Carrion beetles were not compared in this study as a part of the insect succession patterns because the beetles are more of an opportunistic insect that come and utilise remains irregularly over time (Smith 1986). In fact, the study of Barton et al. (2017) highlights this factor that predaceous beetles are more prevalent early on coinciding with high numbers of fly larvae, and beetle scavengers are present late in the decomposition stages. The review on dermestids (beetle scavengers) by Magni et al. (2015) contrasts these results showing that these beetles occur from three days to three years following death.

The results from this study - although the first with a forensic focus in Tasmania - will provide fundamental baseline reference data on fly succession on a carcass. As such, ongoing research in the area of insect succession patterns (flies and beetles) needs to be expanded to include seasonal and habitat types within every geographic region.

At present, a limited but expanding number of studies have been focused on insect succession in Australia (Morris $\&$ Dadour 2015). For example, insect succession patterns have not yet been investigated in most of northern Australia and this becomes a limiting factor in any forensic case conducted there. Furthermore, continuing studies are also required in Tasmania during different seasons, habitat types and should include an array of different circumstantial situations, such as clothed vs unclothed, buried vs exposed, and concealed vs exposed carcasses (Voss et al. 2009).

\section{ACKNOWLEDGEMENTS}

The authors would like to thank C. K. \& S. Farquhar for their support in supplying the pigs for the study and the active rural paddock near Devonport. The Department of Primary Industries, Parks, Water and Environment Facility is thanked for allowing the use of their land in Launceston as the urban decomposition site for the study. We thank Ms Tracey Fong for her contribution to the literature review and the two reviewers for their helpful comments. 


\section{REFERENCES}

Abd El-bar, M.M. \& Sawaby, R.F. 2011: A preliminary investigation of insect colonization and succession on remains of rabbits treated with an organophosphate insecticide in El-Qalyubiya Governorate of Egypt. Forensic Science International 208: 26-30.

Alves, A.C., Santos, W.E., Farias, M.L. \& Creao-Duarte, A.J. 2014: Blowflies (Diptera, Calliphoridae) associated with pig carcasses in a Caatinga area, Northeastern Brazil. Neotropical Entomology 43: 122-126.

Amendt, J., Campobasso, C.P., Gaudry, E., Reiter, C., LeBlanc, H.N. \& Hall, M. 2007. Best practice in forensic entomology. Standards and guidelines. International Journal of Legal Medicine 121: 104-109.

Archer, M.S. \& Elgar, M.A. 2003: Yearly activity patterns in southern Victoria (Australia) of seasonally active carrion insects. Forensic Science International 132: 173-176.

Archer, M.S., Bassed, R.B., Briggs, C.A. \& Lynch, M.J. 2005: Social isolation and delayed discovery of bodies in houses: the value of forensic pathology, anthropology, odontology and entomology in the medico-legal investigation. Forensic Science International 151: 259-265.

Barton, P.S., Evans, M.J., Pechal, J.L. \& Benbow, M.E. 2017: Necrophilous insect dynamics at small vertebrate carrion in a temperate eucalypt woodland. Journal of Medical Entomology 54: 964-973.

Benbow, M.E., Pechal, J.L., Lang, J.M., Erb, R. \& Wallace, J.R. 2015. The potential of high-throughput metagenomic sequencing of aquatic bacterial communities to estimate the Postmortem Submersion Interval. Journal of Forensic Science 60: 1500-1510

Bornemissza, G. 1957: An analysis of arthropod succession in carrion and the effect of its decomposition on the soil fauna. Australian Journal of Zoology 5: 1-12.

Byrd, J.H. \& Castner, J.L. 2010: Forensic Entomology - The Utility of Arthropods in Legal Investigation (Second Edition). CRC Press, Boca Raton, USA: 681 pp.

Byrd, J.H. \& Tomberlin J.K. 2010: Laboratory rearing of forensic insects. In Byrd, J.H. \& Castner, J.L. (eds): Forensic Entomology - The Utility of Arthropods in Legal Investigation (Second Edition) CRC Press, Boca Raton, USA: 177-200.

Bureau of Meteorology 2017: Climate statistics for Australian locations. Commonwealth of Australia, Australia

Campobasso, C.P., Di Vella, G. \& Introna, F. 2001: Factors affecting decomposition and Diptera colonization. Forensic Science International 120: 18-27.

Carvahlo, F., Dadour, I.R., Groth, D.M. \& Harvey, M.L. 2005: Isolation and detection of ingested DNA from the immature stages of Calliphora dubia (Diptera: Calliphoridae): a forensically important blowfly. Forensic Science, Medicine, and Pathology 1: 261-265.

Dadour, I.R., Cook, D.F., Fissioli, J.N. \& Bailey, W.J. 2001: Forensic entomology: application, education and research in Western Australia. Forensic Science International 120: $48-52$.

Di Luise, E., Magni, P.A., Staiti, N., Spitaleri, S. \& Romano, C. 2008: Genotyping of human nuclear DNA recovered from the gut of fly larvae. Forensic Science International: Genetics Supplement Series 1: 591-592.

Farrell, J.F., Whittington, A.E. \& Zalucki, M.P. 2015: A review of necrophagous insects colonising human and animal cadavers in south-east Queensland, Australia. Forensic Science International 257: 149-154.

Forbes, S.L., Perrault, K.A., Stefanuto, P.H., Nizio, K.D. \& Focant, J.F. 2014: Comparison of the decomposition VOC profile during winter and summer in a moist, midlatitude $(\mathrm{Cfb})$ climate. PLOS ONE 9: e113681.

Fuller, M. 1934: The insect inhabitants of carrion: A study in animal ecology. CSIRO Bulletin 9: 5-63.
Gherlenda, A.N., Esveld, J.L., Hall, A.A., Duursma, R.A. \& Riegler, M. 2016: Boom and bust: rapid feedback responses between insect outbreak dynamics and canopy leaf area impacted by rainfall and $\mathrm{CO}_{2}$. Global Change Biology 22: 3632-3641.

Gill, G.J. 2005: Decomposition and Arthropod Succession on Above Ground Pig Carrion in Rural Manitoba. Unpublished $\mathrm{PhD}$ thesis, University of Manitoba, Manitoba.

Goff, M.L. 1991: Comparison of insect species associated with decomposing remains recovered inside dwellings and outdoors on the island of Oahu, Hawaii. Journal of Forensic Science 36: 748-753.

Goff, M.L. 1993: Estimation of postmortem interval using arthropod development and successional patterns. Forensic Science Review 5: 81-94.

Hughes, R.D. 1970: The seasonal distribution of bushfly (Musca vetustissima Walker) in south-east Australia. Journal of Animal Ecology 39: 691-706.

Hyde, E.R., Haarmann, D.P., Petrosino, J.F., Lynne, A.M. \& Bucheli, S.R. 2015: Initial insights into bacterial succession during human decomposition. International Journal of Legal Medicine 129: 661-671.

Iqbal, M.A., Ueland, M. \& Forbes, S.L. 2018: Recent advances in the estimation of post-mortem interval in forensic taphonomy. Australian Journal of Forensic Science DOI: 10.1080/00450618.2018.1459840

Johnson, A.P., Mikac, K.M. \& Wallman, J.F. 2013: Thermogenesis in decomposing carcasses. Forensic Science International 231: 271-277.

Knobel, Z., Ueland, M., Nizio, K.D., Patel, D. \& Forbes, S.L. 2018: A comparison of human and pig decomposition rates and odour profiles in an Australian environment. Australian Journal of Forensic Science 51: 557-572.

Lang, M., Allen, G. \& Horton, B.P. 2006: Blowfly succession from possum (Trichosurus vulpecula) carrion in a sheepfarming zone. Medical and Veterinary Entomology 20: 445-452.

Luong, S., Forbes, S.L., Wallman, J.F. \& Roberts, R.G. 2018. Monitoring the extent of vertical and lateral movement of human decomposition products through sediment using cholesterol as a biomarker. Forensic Science International 285: 93-104.

Magni, P.A., Petersen, C., Georgy, J. \& Dadour, I.R. 2019: The effect of suitcase concealment on insect colonization: a pilot study in Western Australia. Global Journal of Forensic Science \& Medicine 1: 1-9.

Magni, P.A., Pazzi, M., Droghi, J., Vincenti, M. \& Dadour, I.R. 2018: Development and validation of an HPLC-MS/ MS method for the detection of ketamine in Calliphora vomitoria (L.) (Diptera: Calliphoridae). Journal of Forensic and Legal Medicine 58: 64-71.

Magni, P.A., Voss, S.C., Testi, R., Borrini, M. \& Dadour, I.R. 2015: A biological and procedural review of forensically significant dermestes species (Coleoptera: Dermestidae). Journal of Medical Entomology 52: 755-769.

Marks, M.K., Love, J.C. \& Dadour, I.R. 2010: Taphonomy and time: estimating the postmortem interval. In D. Steadman (ed.), Hard Evidence: Case Studies in Forensic Anthropology (Second Edition). CRC Press: pp. 165-178.

McCalman, I., 2009: Darwin's Armada. Penguin Books: 423 pp.

McIntosh, C.S., Dadour, I.R. \& Voss, S.C. 2017: A comparison of carcass decomposition and associated insect succession onto burnt and unburnt pig carcasses. International Journal of Legal Medicine 131: 835-845.

Mégnin, J.P. 1894: La faune de cadavres. Application de l'entomologie à la médicine légale. Encyclopedie Scientifique des AideMémoire. G. Masson, Paris: 214 pp.

Monzu, N. 1977: Coexistence of Carrion Breeding Calliphoridae (Diptera) in Western Australia. Unpublished PhD thesis, University of Western Australia. 
Morris, B. \& Dadour, I.R. 2015: Insects and their uses in legal cases. In Freckleton, I. \& Selby, H. (eds): Expert Evidence. The Law Book Company Limited: P8-5291-5298-5381.

O'Brien, R.C., Forbes, S.L., Meyer, J. \& Dadour, I.R. 2007: A preliminary investigation into the scavenging activity on pig carcasses in Western Australia. Forensic Science, Medicine and Pathology 3: 194-199.

O'Flynn, M.A. 1983: The succession and rate of development of blowflies in carrion in southern Queensland and the application of these data to forensic entomology. Journal of the Australian Entomological Society 22: 137-148.

Payne, J.A. 1965: A summer carrion study of the baby pig Sus scrofa Linnaeus. Ecology 46: 592-602.

Roberts, L.G., Spencer, J.R. \& Dabbs, G.R. 2017: The effect of body mass on outdoor adult human decomposition. Journal of Forensic Science 62:1145-1150

Schoenly, K.G. \& Hall, R.D. 2002: Testing Reliability of Animal Models in Research and Training Programs in Forensic Entomology. NIJ Report: 34 pp.

Schotsmans, E.M., Forbes, S.L. \& Márquez-Grant, N. 2017: Taphonomy of Human Remains: Forensic Analysis of the Dead and the Depositional Environment. John Wiley \& Sons: $452 \mathrm{pp}$.
Smith, K.G.V. 1986: A Manual of Forensic Entomology. Trustees of the British Museum, London: 205 pp.

Voss, S.C., Forbes, S.L. \& Dadour, I.R. 2008: Decomposition and insect succession on cadavers inside a vehicle environment. Forensic Science, Medicine, and Pathology 4: 22-32.

Voss, S.C., Spafford, H. \& Dadour, I.R. 2009: Annual and seasonal patterns of insect succession on decomposing remains at two locations in Western Australia. Forensic Science International 193: 26-36.

Voss, S.C., Cook, D.F. \& Dadour, I.R. 2011: Decomposition and insect succession of clothed and unclothed carcasses in Western Australia. Forensic Science International 211: 67-75.

Wallace, D.R. 2017: Evolution of forensic entomotoxicology. Toxicololgy and Forensic Medicine Open Journal: SE(1) Se1-Se4, https://doi: 10.17140/TFMOJ-SE-1-e001.

Wallman, J.F. \& Adams, M.D. 1997: Molecular systematics of Australian carrion-breeding blowflies of the genus Calliphora (Diptera:Calliphoridae). Australian Journal of Zoology 45: 337-356.

Zumpt, F. 1965: Myiasis in Man and Animals in the Old World. Butterworths, London: 267 pp.

(Accepted 15 August 2019) 